\title{
EDUCAÇÃO PARA APENADOS: DESAFIOS E PERSPECTIVAS
}

\section{ARTIGO ORIGINAL}

SANTOS, Maria Eliane Ferreira dos ${ }^{1}$

MEDEIROS, Késia Girlane Santos de ${ }^{2}$

SANTOS, Maria Eliane Ferreira dos. MEDEIROS, Késia Girlane Santos de. Educação para apenados: Desafios e perspectivas. Revista Científica Multidisciplinar Núcleo do Conhecimento. Ano 05, Ed. 10, Vol. 20, pp. 144-160. Outubro de 2020. ISSN: 24480959, Link de acesso: https://www.nucleodoconhecimento.com.br/educacao/educacao-paraapenados

\section{RESUMO}

O presente trabalho tem por finalidade apresentar os entraves que surgem no processo educacional em prisões, haja vista a falta de políticas públicas adequadas para investir em uma educação de qualidade para alunos privados de liberdade. Através das leituras realizadas é possível perceber que há muito tempo já existia um descaso por parte dos governantes e da sociedade. A partir do século $X X$, alguns investimentos surgem aos poucos, mas ainda nos deparamos com uma educação desvalorizada, pelos governantes e pela sociedade. A finalidade é demonstrar que apesar dos entraves, é possível resgatar a história do apenado e levá-lo a construir uma família e voltar a conviver em meio a sociedade com dignidade. A educação em prisões é um grande desafio, mas sabe-se das possibilidades e mesmo diante dos

\footnotetext{
${ }^{1}$ Doutoranda em Ciências da Educação (cursando), Mestra em Ciências da Educação (concluído), Pós-Graduação em Organização e Gestão Escolar, Pós Graduada em Língua Portuguesa e Literatura, Graduação em Letras e Normal Superior.

${ }^{2}$ Mestra em Ciências da Educação (concluído), Graduação em Letras (Concluído) e, Graduação em Nutrição (cursando).
} 
entraves temos nos deparados com resultados positivos de alunos que buscam conhecimento, constroem saberes e possuem uma inteligência indiscutível. A "educação prisional" é uma importante garantia de um recomeço para uma ressocialização, pois através da sala de aula é possível garantir aos alunos privados de liberdade, dignidade, haja vista os espaços dos quais eles fazem parte é de total desprezo pela vida, na sala de aula, o apenado sente-se gente de novo, sente-se apto para enfrentar os desafios da vida e até mesmo retomar uma vida íntegra na sociedade. Vale salientar que uma educação de boa qualidade nas prisões, evita rebeliões e há uma redução de pena para quem frequenta a escola. Isso porque a Lei de Execução Penal determina que 12 horas de frequência escolar equivalem a um dia a menos de pena. A educação é um direito que deve ser garantido a todos, assim como assegura a Lei de Diretrizes e Bases da Educação Nacional, no artigo 205, que declara o acesso a educação como um direito de todos, de modo a ser promovida e incentivada pela sociedade, priorizando o desenvolvimento e a preparação de um indivíduo na sociedade, logo, refere-se ao aluno privado de liberdade.

Palavras-chaves: Entraves, sociedade, ressocialização, liberdade.

\section{INTRODUÇÃO}

Esta pesquisa tem como objetivo apresentar o grande dilema da educação prisional no Brasil, obstáculos que até então, ainda não é possível encontrar uma solução apropriada, haja vista a falta de uma política pública adequada para o ensino em prisões, pois o mesmo é apresentado na modalidade de Educação de Jovens e Adultos (EJA). Acredita-se que por isso, tantos empecilhos são enfrentados por alunos privados de liberdade.

Segundo Novo (2019), o homem nasceu para ser livre, não faz parte da sua natureza permanecer enjaulado. Mesmo que a escola seja um refúgio, ainda assim é possível deparar-se com discentes que afirmam de forma segura, não haver interesse pela sala de aula, mas muitas vezes, ele procura esse espaço para fugir das punições, ou seja, a prisão é vista como um lugar que pune, persegue, maltrata, humilha, e o preso por não suportar tantas humilhações ver na escola um lugar de conforto e segurança. 
Ainda segundo Foucault (1987), a prisão se fundamenta na "privação de liberdade", salientando que esta liberdade é um bem presente a todos da mesma maneira, ou seja, perdê-la, significa perder o direito de ir vir, e demonstra principalmente que o fato de não ser livre, logo, sofrerá as consequências relacionadas aos atos infracionários cometidos pelos presos.

\section{METODOLOGIA}

O presente artigo foi elaborado a partir de uma pesquisa bibliográfica de várias vertentes e autores que se dispuseram a falar sobre o confronto da educação prisional, pesquisa esta, realizada através da internet, leitura exaustiva em diversas fontes, na busca incessante de compreender os desafios da EJA no contexto prisional, e buscar de forma clara e objetiva, para assim compreender um pouco do contexto histórico e a finalidade da educação em prisões.

A análise dessa pesquisa e das informações aqui apresentadas, surgem de acordo com a compreensão das leituras realizadas, ou seja, são essas leituras que trazem uma gama de possibilidades de compreender melhor o enfrentamento da educação prisional, principalmente no que diz respeito aos professores que fazem parte desse processo.

\section{DESENVOLVIMENTO}

\subsection{EDUCAÇÃO PRISIONAL: UM DESAFIO CONSTANTE}

Para compreender a história da educação prisional, é importante conhecer o contexto histórico do sistema prisional brasileiro, que no decorrer do tempo, sofreu grandes modificações, sempre em busca de compreender as idas e vindas do apenado. Não é possível falar sobre educação prisional sem antes conhecer os principais fatos que foram modificados ao longo do tempo.

No período colonial, o Brasil era regido pelas "Ordenações", de "Portugal. Assim, o Código Filipino foi um marco bastante relevante nesta época, que aboliu as últimas 
Ordenações (Manuelinas). Esse Código foi considerado pela história como uma legislação alheia aos direitos humanos, pois acarretava penas cruéis, degradantes e vis, com aspecto de vingança corporal (SCHICHOR, 1993).

Esse código retrata uma desigualdade social no que diz respeito aos menos favorecidos, haja vista o fato dos ricos sofrerem penas mais brandas. Um exemplo clássico da execução destas penas é a condenação à morte de Tiradentes que demostra a crueldade e o alheamento à humanização da pena:

Portanto condenam ao Réu Joaquim José da Silva Xavier por alcunha o Tiradentes Alferes que foi da tropa paga da Capitania de Minas a que com baraço e pregão seja conduzido pelas ruas públicas ao lugar da forca e nela morra morte natural para sempre, e que depois de morto the seja cortada a cabeça e levada a Villa Rica aonde em lugar mais público dela será pregada, em um poste alto até que o tempo a consuma, e o seu corpo será dividido em quatro quartos, e pregados em postes pelo caminho de Minas no sitio da Varginha e das Sebolasa, onde o Réu teve as suas infames práticas e os mais nos sítios de maiores povoações até que o tempo também os consuma; declaram o Réu infame, e seus filhos e netos tendo-os, e os seus bens aplicam para o Fisco e Câmara Real, e a casa em que vivia em Villa Rica será arrasada e salgada, para que nunca mais no chão se edifique e não sendo própria será avaliada e paga a seu dono pelos bens confiscados e no mesmo chão se levantará um padrão pelo qual se conserve em memória a infâmia deste abominável Réu. (apud DOTTI, 2003, p. 27)

As leis próprias do Brasil só foram desenvolvidas com a Constituição do Império, em 1824. Assim.: "[...] em 1824, foi outorgada a primeira constituição. Esta trazia garantias a liberdade pública e dos direitos individuais. O novo diploma legal previu a necessidade de um código criminal, que deveria ter pilares fundados na justiça e equidade" (TAKADA, 2010, p. 3). Ou seja, percebe-se que as leis sempre estiveram presentes na sociedade, no entanto as mesmas eram feitas como uma forma de repressão, de afastamento do indivíduo incapaz de conviver em sociedade.

Deste modo, o Código Criminal do Império começou a atuar juridicamente com uma vertente mais humana, aderindo como pena a privação de liberdade.

Posteriormente, com a introdução de um sistema republicano, foi criado um novo Código, de 1890 com penas mais brandas se comparado as do Código Criminal do 
Império. Entretanto, ainda assim, há um quê de repressão e segregação social sempre existiu no Brasil.

Compreende-se nesse contexto que até então o dito "Educação" ainda não era algo previsto na lei, todo o contexto histórico é formado por um afastamento desse indivíduo da sociedade, haja vista ainda não existir leis que abordem a questão da ressocialização e de escolas funcionando nas chamadas "cadeias" e/ou presídios. Não se pode falar sobre educação prisional, sem antes abordar as diversas questões do próprio sistema, como as leis que regiam o país, haja vista as mudanças que ao longo do tempo foram aprimoradas para assim possibilitar o privado de liberdade a frequentar uma sala de aula.

A educação no sistema penitenciário iniciou na década de 1950. Ainda no início do Século XIX, a prisão era tida como apenas um local de contenção de pessoas, sem qualquer proposta de requalificar os presos.[3] De acordo com estudos realizados não havia uma educação que abrangesse o privado de liberdade, este por sua vez ficava a mercê de todo tipo de violência, não existia nenhuma política pública que beneficiasse o preso, a vida não tinha valor.

No entanto, com o desenvolvimento de programas de tratamento dentro das prisões, surgiu esta proposta. Anteriormente, não existia nenhuma forma de trabalho, ensino religioso ou laico.

Portanto, no início dos anos de 1950 identificou-se o insucesso deste sistema prisional, que consequentemente motivou a busca de novas direções, inserindo assim a educação escolar nas prisões. Foucault (1987, p. 224) diz: "A educação do detento é, por parte do poder público, ao mesmo tempo uma precaução indispensável no interesse da sociedade e uma obrigação para com o detento, ela é a grande força de pensar".

No século XX percebeu-se que a população carcerária, por conta da segregação social, que é patente no Brasil, não tinha muita instrução ou atingia um padrão alto no 
que diz a respeito à educação formal. Sendo assim, por volta de 1950, houve a incorporação da educação no sistema penitenciário.

Inicia então uma nova concepção sobre o sistema penitenciário, no que diz respeito a prisão, só a partir dessas mudanças no Brasil, em meados de 1950, as Normas Gerais do Regime Penitenciário (Lei $n^{\circ}$ 3274/57) foram editadas e aceitas como aquela que inaugurou a concepção educacional integral para a população carcerária (VASQUEZ, 2008).

\subsection{EDUCAÇÃO EM PRISÕES: ESPERANÇA PARA NOVAS OPORTUNIDADES}

Só a partir do governo de Juscelino Kubitschek essas Normas Gerais do Regime Penitenciário foram ratificadas, apresentando termos como "educação moral", "educação intelectual", "educação física", "educação artística" e "educação profissional" (VASQUEZ, 2008, p. 70). O principal objetivo seria o de aprimorar no cotidiano do cárcere uma educação de qualidade, que pudesse inserir o indivíduo privado de liberdade na tentativa de ofertar uma melhor condição de vida para aqueles que se encontram sem o direito de conviver em sociedade, mas infelizmente não foi bem consolidado, por falta de uma organização eficiente, o que demonstra a realidade nacional de descaso com os presídios brasileiros.

A educação é um direito garantido por lei, haja vista, a possibilidade de mudanças, do enfrentamento contra a miséria, a tentativa de diminuir a violência e fazer com que essa população carcerária tenha um mínimo de dignidade, transforme suas vidas, se tornem mais humanos, sendo capazes de criar em si, a esperança de conquistar novas oportunidades, e que possam a partir da educação enfrentar a sociedade.

Ela é a base, ou seja, uma das principais ferramentas para o crescimento pessoal, através dela é possível transformar, ampliar o conhecimento de mundo, principalmente levar o privado de liberdade a valorizar mais a vida, e as pessoas que o cercam, quando estes conseguem compreender que a escola é o seu lugar de refúgio. Vale salientar que se faz necessário investir em uma política educacional de qualidade, aprimorando o valor humano, a inclusão social, cultura e econômica. 
Em relação às políticas de educação escolar nas prisões, ressalta-se o seu caráter complexo de organização e funcionamento, pois se realizam a partir da articulação do sistema de educação com o sistema penitenciário (Ministério da Educação, Ministério da Justiça, Secretarias Estaduais de Educação e Secretarias de Defesa Social ou Administração Prisional, além de órgãos integrantes desses sistemas, como os presídios e as penitenciárias), que, por sua vez, articula-se com o sistema de justiça penal e com a sociedade. (OLIVEIRA, 2013, p. 957).

Neste contexto, a Constituição Federal de 1988, considerada a mais democrática e cidadã de todas as Constituições brasileiras, assegura em seus princípios, bases voltadas a compreensão da educação em sistemas previdenciários como questão de direitos humanos fundamentais e sociais. Logo, investir em escolas prisionais implica em vários aspectos, dentre eles, está a possibilidade de devolver esse sujeito à sociedade, para o convívio com familiares, amigos, acesso ao trabalho, o retorno ao sentido da palavra vida. Entretanto, para falar de educação prisional, se faz necessário apresentar as leis que rege a instituição.

Art. 1ํ A República Federativa do Brasil, formada pela união indissolúvel dos Estados e Municípios e do Distrito Federal, constitui-se em Estado Democrático de Direito e tem como fundamentos:

I - a soberania;

II - a cidadania;

III - a dignidade da pessoa humana; [...]. (BRASIL, 1988)

Neste contexto, a Lei de Execução Penal - LEP, (Lei ㄲo 7.210/84) aborda, precisamente, como se deve conduzir o cumprimento da pena em estabelecimentos penais:

Art. 1ำ A execução penal tem por objetivo efetivar as disposições de sentença ou decisão criminal e proporcionar condições para a harmônica integração social do condenado e do internado.

\section{$[\ldots]$}

Art. $3^{\circ}$ Ao condenado e ao internado serão assegurados todos os direitos não atingidos pela sentença ou pela lei. (BRASIL, 1988). 
Nos artigos 10 e 11 da LEP, é descrito claramente que o Estado tem total responsabilidade de garantir a efetivação de tais direitos:

Art. 10. A assistência ao preso e ao internado é dever do Estado, objetivando prevenir o crime e orientar o retorno à convivência em sociedade.

Parágrafo único. A assistência estende-se ao egresso.

Art. 11. A assistência será:

I - Material;

II - À saúde;

III -jurídica;

IV - Educacional;

V - Social;

VI - Religiosa. (BRASIL, 1984, grifo nosso)

Por fim a Constituição Federal de 1988, em seu artigo 6º

Art. 6ํ․ São direitos sociais a educação, a saúde, o trabalho, a moradia, o lazer, a segurança, a previdência social, a proteção à maternidade e a infância, a assistência aos desamparados, na mesma forma desta constituição.

Refere-se, assim, ao direito social que exige uma assistência positiva do Estado.

Que estando o indivíduo em cárcere ou não, nada o prive dos seus direitos, tais como a saúde e o trabalho.

Vale salientar que a educação também é primordial no sistema carcerário, é a possibilidade de mudanças na vida desse indivíduo, é o resgate da autoestima, mas é também a conscientização da sociedade em compreender que o cidadão ao perder sua liberdade, também perde um pouco de si.

A possibilidade de devolver esse indivíduo para a sociedade quando o mesmo estuda é muito maior, do que quando este não procura a escola. É lá na sala de aula que se 
dá o processo transformador, de crescimento, aprimoramento e aperfeiçoamento. A escola prisional pode não ser a melhor escolha para os privados de liberdade, mas é o momento de refúgio, é a possibilidade de mudanças, haja vista, além da construção pelo conhecimento este por sua vez terá sua pena reduzida. Quanto mais ele se dedica a escola, mais acesso ao conhecimento e a chance de voltar para ao convívio familiar.

Vale salientar que mediante todo contexto socioeducativo percebe-se a falta de investimentos na educação prisional, pois esta já vem de longos anos no enfretamento de dificuldades no que diz respeito a sua existência dentro dos presídios, pois ao mesmo tempo que esta poderia ser a porta de saída, para os governantes é apenas um gasto desnecessário. A sociedade não vê de bom grado, para ela, o preso não tem que ter "regalias", ou seja, a partir do momento que o indivíduo pratica um crime, precisa assumir e pagar pelo mesmo.

No entanto às pessoas que estão dentro do sistema carcerário, seja feminino ou masculino tem direito ao acesso escolar, destaca-se na Declaração Universal dos Direitos Humanos, no artigo 26, que todos tem direito a educação, visando o pleno desenvolvimento do indivíduo e o reafirmamento do respeito aos direitos humanos. (OLIVEIRA, 2013)

Entende-se que esses direitos são dados a todo e qualquer cidadão (a), pois a finalidade dele, não é punir, mas garantir a legalidade desses direitos para os privados de liberdades com o intuito de conscientizá-los de seu papel na sociedade, principalmente ao convívio com as demais pessoas. O presídio não muda, mas a escola tem esse poder transformador, um papel importantíssimo na construção de identidade desse preso. E não é algo incitado por qualquer pessoa, mas existem leis que garantem o acesso à escola:

O sistema carcerário brasileiro é advindo de problemas sociais. De acordo com os dados registrados em 2017, atualmente, existem 668.182 presos no Brasil, enquanto os números de vagas é de 394.835 , resultando na superlotação com um percentual 
equivalente a 69,2\%. Assim, exige do Estado políticas públicas, objetivando uma intervenção para realização de mudanças.

No caso do sistema carcerário, o benefício recai não só aos detentos, mas também a sociedade. (VELASCO, 2017)

Esse direito está previsto em diversos documentos internacionais, tais como: Declaração Mundial sobre Educação para Todos (artigo $1^{\circ}$ ); Convenção Internacional sobre os Direitos da Criança (parágrafo 1ํㅡㄹ art. 29); Convenção contra a Discriminação

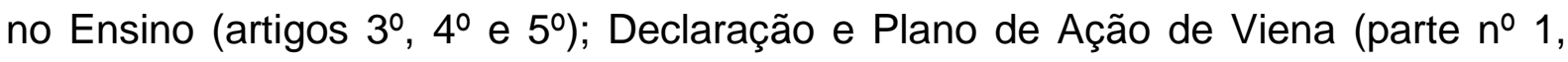
parágrafo 33 e 80); Agenda 21 (capítulo 36); Declaração de Copenhague (compromisso no 6); Plataforma de Ação de Beijing (parágrafos 69, 80, 81 e 82); Afirmação de Aman e Plano de Ação para o Decênio das Nações Unidas para a Educação na Esfera dos Direitos Humanos (parágrafo 2º). (PRADO, 2017)

Os desafios enfrentados são grandes, porém possíveis de enfrentá-los, a lei garante o acesso, o trato igualitário para todos, independentemente de sua liberdade ou não. Educação é um direito de todo e qualquer cidadão, é através dela a possível conquista, porém, sabe-se que investimentos são cada vez mais escassos, não há políticas públicas adequadas para assim impedir esse crescimento desenfreado das desigualdades sociais, o que torna o preso a mercê da exclusão, a falta de afetividade familiar, e esse indivíduo cada dia mais carente e propenso a retornar ao mundo do crime.

A escola é o seu lugar de refúgio, é a busca pelo resgate de identidade, a vontade de vencer longe da criminalidade, vale ressaltar que a prisão já é um processo de discriminação, de exclusão, a escola é vista como um lugar de conquista. É nesse sentido que esse estudo procura investigar como acontece a implementação das Políticas Públicas para a Educação de jovens e Adultos (EJA) em situação de privação de liberdade, como essa inserção se dá, e o que de fato tem tornado esse espaço mais atrativo para esse indivíduo. (NASCIMENTO, 2013) 
Por sua vez, surgem outros questionamentos, o detento vai à escola apenas pela remição, ou esta busca aprimorar seus conhecimentos? Qual o objetivo de um detendo enfrentar a sala de aula? Os questionamentos são os mais diversificados, no entanto vale ressaltar que 0 [i] convívio com essa realidade traz outros questionamentos, como por exemplo: é possível ser aceito pela sociedade? É possível arrumar um emprego para não voltar a praticar os mesmos delitos? Para algumas dessas perguntas temos respostas bem contundentes, para outras não.

O Direito à Educação é garantido às pessoas presas pela Declaração Universal dos Direitos Humanos (1948); no ordenamento jurídico brasileiro pela Constituição Federal (1988), Lei de Diretrizes e Bases de Educação (1996) e pela Lei de Execução Penal (1984). (SILVA, 2013).

O nível educacional das pessoas que ingressam no sistema carcerário, geralmente é muito baixo, e isso acarreta grandes dificuldades no mercado de trabalho, nesse caso era necessário mais investimento, ou seja, uma política pública bem elaborada e bem administrada para investir fortemente na educação. Ao refletir sobre a situação do apenado no Brasil, observa-se que a maioria dos presos não tiveram as melhores oportunidades no que diz respeito a educação, não estudavam, não se dava o direito de ir e vir do preso, a permissão para visita familiares era quase que inexistente, (BRASIL ESCOLA, 2017).

Vale ressaltar que diante de tantas investidas mal sucedidas no que diz respeito a inclusão de indivíduos aprisionados de volta as relações sociais e a valorização da educação prisional, observa-se que o modelo, dessa forma educativa no Brasil localiza-se no Estado de São Paulo. Tavolaro (1999), relata que no início não havia participação da sociedade. De acordo com o contexto histórico da educação de presos no Estado, até 1979, professores comissionados pela Secretaria de Educação lecionavam o ensino básico nos presídios, baseando em anos letivos de escolas oficiais, com seriação anual e o uso do material-pedagógico aplicado as crianças. Percebe-se que não havia uma prática pedagógica capaz de atender às necessidades do apenado, só no ano de 1988, quando a responsabilidade pela educação de presos foi conferida a Fundação Estadual de Amparo ao Trabalhador 
Preso- FUNAP, designada a remuneração dos monitores, funcionamento das escolas e metodologia de ensino aplicada.

Eis que surge vários questionamentos, qual a finalidade do preso estar em sala de aula? Há interesse por parte dos governantes e da sociedade que este seja inserido em um programa de reeducação? De acordo com pesquisas anteriormente realizadas, percebe-se que essa "reeducação" que objetiva o estado na prática não existe. Pois o que de fato chama atenção nesse aspecto é que a maior preocupação do sistema penitenciário ao receber um indivíduo condenado não está na sua reeducação, mas sim na sua privação de liberdade. (SANTOS, 2008.).

Ou seja, ao ingressar no presídio o indivíduo já está condenado a viver uma vida medíocre, de migalhas, a sociedade o descarta e esquece que um dia ele já fez parte desse processo. A família na maioria das vezes também o abandona e este segue se envolvendo cada vez mais no mundo da criminalidade, não existem motivos suficientes para uma reinserção, o sujeito sente-se desprezado, incapaz de voltar a acreditar em si mesmo. Segundo Claude, ele diz que:

A educação é valiosa por ser a mais eficiente ferramenta para crescimento pessoal. E assume o status de direito humano, pois é parte integrante da dignidade humana e contribui para ampliá-la como conhecimento, saber e discernimento. Além disso, pelo tipo de instrumento que constitui, trata-se de um direito de múltiplas faces: social, econômica e cultural. Direito social porque, no contexto da comunidade, promove o pleno desenvolvimento da personalidade humana. Direito econômico, pois favorece a autossuficiência econômica por meio do emprego ou do trabalho autônomo. E direito cultural, já que a comunidade internacional orientou a educação no sentido de construir uma cultura universal de direitos humanos. Em suma, a educação é o pré-requisito para o indivíduo atuar plenamente como ser humano na sociedade moderna. (CLAUDE, 2005).

Neste contexto, pode-se identificar que a privação da liberdade não contribui para a ressocialização. Sendo assim, é necessária alguma realização voltada a este sentido, a fim de mitigar ou até mesmo resolver esse equívoco. Para isso é necessário que seja desenvolvido programas educacionais apropriados para o sistema penitenciário que possa alcançar a sociedade carcerária de um modo geral, por isso a Educação 
de Jovens e Adultos visa alfabetizar e trabalhar a construção da cidadania do apenado. Conforme Salla (1999, p. 67) "[...] por mais que a prisão seja incapaz de ressocializar, um grande número de detentos deixa o sistema penitenciário e abandona a marginalidade porque teve oportunidade de estudar".

Quando o preso tem a oportunidade de ser inserido em sala de aula, observa-se uma mudança de comportamento surpreendente, ele passa a pensar muito mais na família, no resgate da própria identidade, na busca de fortalecer os laços familiares, nesse momento percebe-se que a EJA é a única porta capaz de reescrever essa história.

\subsection{A IMPORTÃNCIA DA EDUCAÇÃO PARA ALUNOS PRIVADOS DE LIBERDADE}

O texto em questão não está querendo mostrar a situação dos presídios brasileiros, mas a importância da educação dentro sistema, mas é preciso abordar questões que são pertinentes para assim compreender melhor a situação do sistema de um modo geral. O aspecto mais relevante e de possível consideração é observar o perfil da população carcerária no Brasil, de acordo com dados fornecidos pelo Departamento Penitenciário Nacional do Ministério da Justiça, no Brasil, a maior parte da massa carcerária é composta por jovens com menos de trinta anos de idade e de baixa escolaridade, em número consideravelmente assustador, (97\% são analfabetos ou semianalfabetos). (SANTOS, 2008).

Logo, a criminalidade está interligada ao baixo nível de escolaridade e ambas a questão econômica social. De forma que precisam urgentemente elaborar projetos educacionais que possam trabalhar a conscientização dos educandos, para assim levá-los a compreender a realidade e consequentemente seu lugar nesse mundo. Segundo Silva (2008), um indivíduo que nasce desfavorecido, sem qualquer acesso a uma educação, não está apto a agir com discernimento em seus atos. Gadotti salienta que:

A necessidade de trabalhar no reeducando "[..] o ato antissocial e as consequências desses atos, os transtornos legais, as perdas pessoais $\mathrm{e}$ o estigma social". Em outras palavras, desenvolver nos educandos a 
capacidade de reflexão, fazendo-os compreender a realidade para que de posse dessa compreensão possam então desejar sua transformação. (GADOTTI, 1999, p.62).

Ou seja, uma educação que possa ser capaz de assumir uma autonomia intelectual dos alunos, ofereça condições de analisar e compreender a realidade prisional humana e social em que estes vivem. O sistema penitenciário necessita urgentemente de uma educação que tenha a preocupação prioritária de desenvolver a capacidade de criticidade, capaz de envolvê-los na possibilidade de alertá-los para as escolhas que precisam fazer ao longo da vida, inclusive do período em que estes são indivíduos pertencentes a sua convivência, o presídio.

De acordo com Gadotti (1999), a educação liberta e dentro da prisão a palavra e o diálogo, são considerados a principal chave. A única motivação de um preso é a liberdade, e a liberdade é a força de pensar

Em sua análise Freire (1980), afirma que:

A conscientização é, [...] um teste de realidade. Quanto mais conscientização, mais se "desvela" a realidade, mais se penetra na essência fenomênica do objeto, frente ao qual nos encontramos para analisá-lo. Por esta mesma razão, a conscientização não consiste em "estar frente à realidade" assumindo uma posição falsamente intelectual. A conscientização não pode existir fora das "práxis", ou melhor, sem o ato ação-reflexão. Esta unidade dialética constitui, de maneira permanente, o modo se ser ou de transformar o mundo que caracteriza os homens. (FREIRE, 1980, p. 26).

Sob a perspectiva da educação, deve-se trabalhar com os carcerários conceitos fundamentais, tais como a família, o amor, a dignidade, a liberdade, a cidadania, a miséria, a comunidade, dentre outros. Pois esta tem a função de desmistificar uma realidade importantíssima, a de que a educação dentro do sistema penitenciário dará o passo mais importante, o verdadeiro sentido de ressocialização, a busca de superar o falso argumento de que, uma vez bandido, bandido sempre".

A educação nas unidades prisionais é prevista na LEP: 
Art. 17. A assistência educacional compreenderá a instrução escolar e a formação profissional do preso e do internado. Art. 18. O ensino de 1ํㅡㄴ grau será obrigatório, integrando-se no sistema escolar da Unidade Federativa. Art. 18-A. O ensino médio, regular ou supletivo, com formação geral ou educação profissional de nível médio, será implantado nos presídios, em obediência ao preceito constitucional de sua universalização. $\S 1^{\circ} \mathrm{O}$ ensino ministrado aos presos e presas integrarse-á ao sistema estadual e municipal de ensino e será mantido, administrativa e financeiramente, com o apoio da União, não só com os recursos destinados à educação, mas pelo sistema estadual de justiça ou administração penitenciária. § $2^{\circ}$ Os sistemas de ensino oferecerão aos presos e às presas cursos supletivos de educação de jovens e adultos. (BRASIL, 1984).

De acordo com pesquisas realizadas nessa perspectiva de verificar a EJA, percebese que toda sua estrutura está baseada em normas e leis que regulamentam essa modalidade, haja vista o privado de liberdade não poder usufruir do direito de se locomover para uma escola comum, este por sua vez para não perder o foco dos estudos, busca na prisão uma forma de se reencontrar, e até mesmo se preparar por meio dos estudos para um retorno a sociedade.

A educação no sistema penitenciário segue as regras de direitos humanos, ou seja, o fato de o indivíduo está preso não lhe tira o direito ou a confiscação dos estudos, este por sua vez vai em busca da remição, e se depara com realidades das mais diversificadas e começa perceber, que é muito mais valoroso a busca pelo conhecimento, o envolvimento com o universo dos livros, do que mesmo o envolvimento com um simples documento para diminuição da pena.

Estudiosos, como Foucault começaram a defender a educação como um direito do preso: "A educação do detento é, por parte do poder público, ao mesmo tempo uma precaução indispensável no interesse da sociedade e uma obrigação para com o detento, ela é a grande força de pensar" (FOUCAULT, 1987, p. 224).

Ou seja, é através da educação, os primeiros passos para uma nova vida, para perspectivas diferenciadas no que diz respeito ao convívio em sociedade. Para essa modalidade educacional vale salientar que cada época foi surgindo novas ideias, e sendo aprimoradas para que fosse possível um trabalho diferenciado e qualitativo. Se 
o preso estuda, não procura confusão, está sempre apto para atender às necessidades do sistema, disposto a mudar de vida, a busca pela dignidade é um marco essencial na sua existência. Observa-se que desde período colonial, Paiva (1987) afirma que essa educação era reduzida à alfabetização, que tinha como objetivo a doutrinação dos índios adultos para aceitarem a dominação portuguesa; esse mesmo ensino era direcionado aos filhos dos índios no ensino de língua portuguesa e catequese.

Mesmo no Império, não houve mudanças substanciais dessa concepção. É somente na República que encontramos uma valorização maior dessa educação, porque estava vinculada à ideia de preparação da mão de obra para o desenvolvimento econômico que o país trilhava. Isso ocorre, especificamente, a partir da "revolução de 1930 que encontraremos no país movimentos de educação de adultos de alguma significação". (PAIVA, 1987, p. 165).

Ao refletir sobre o período colonial subtendem-se que a educação para aqueles que perderam seu direito de ir e vir já era desvalorizada, ou seja, uma vez que o indivíduo abriu mão do convívio em sociedade este deveria pagar pelo seu crime e viver de forma degradante, só então na República inicia-se uma nova etapa, um olhar mais aguçado para a oferta de uma educação igualitária para todos.

Ao retirar o direito de ir e vir de uma pessoa, encarcerando-a, é lhe tirado o direito de convivência em sociedade, mantendo-a em um espaço que foi planejado para impedilo de viver afastado do resto da sociedade.

Ao se pensar em educação no espaço da prisão, há de se refletir sobre os limites impostos com clareza, contudo não se deve reduzir o processo educativo, pois como qualquer outro espaço, há de se pensar e entender os interesses e as necessidades de aprendizagem daquele indivíduo que está recluso, e quais limites e determinadas situações estão impostas sobre esse processo educacional.

Para retratar a questão da educação prisional é preciso tratar de uma lamentável ocorrência, o crescente índice de violência e da criminalidade que resultou recentemente a um grande aumento da população carcerária, fato este que se dá não apenas no Brasil, mas na América Latina de um modo geral. 
Quando se fala da oferta de educação no contexto carcerário, é preciso abordar uma discussão mais ampla no que diz respeito a Educação de Jovens e Adultos (EJA), defendendo que essa modalidade em ambiente de reclusão é específica, ou seja, o seu maior intuito é alcançar um público marginalizado, porém não menos provido do direito ao acesso à educação. Ao perceber a centralidade educacional, e a possibilidade de uma nova oportunidade de convivência e dignidade, compreende-se outros fatores essenciais na vida desse cidadão, ou seja, o direito à educação, saúde, um trabalho dentro do próprio sistema, para que este sinta-se parte do processo e saiba que ele está ali por desobedecer regras impostas pela própria sociedade.

A Declaração Universal de Direito Humanos de 1948 afirma claramente o direito de "toda pessoa" a "instrução, direito esse reforçado pelo Pacto Internacional sobre Direitos Econômicos, Sociais e Culturais de 1966, e entendido como o "pleno desenvolvimento da personalidade humana e do sentido da sua dignidade" e o fortalecimento do 'respeito pelos direitos humanos e a liberdades funcionais" (art. 13).

No que diz respeito à população prisional, as regras mínimas para tratar os reclusos, das Nações Unidas (1955), determina que todos os presos devem ter o direito a participar em atividades culturais e educacionais. Portanto esse princípio no Brasil, de acordo com a Lei de Execução penal de 1984, explicita no seu artigo $3^{\circ}$ que ao condenado e ao interno serão garantidos todos os direitos não atingidos pela sentença ou pela lei. (IRELAND, 2011).

\section{CONSIDERAÇÕES FINAIS}

Atuar como professor de educação em prisões é uma tomada de decisão desafiadora, por tratar-se de algo diferente, de uma realidade até então desconhecida, mas ao fazer parte do processo e conhecer mais de perto a realidade enfrentada pelos alunos privados de liberdade, surgem fatos importantíssimos, que fazem todo um diferencial no trabalho de qualquer docente.

Percebe-se que não é qualquer professor que está apto para the dar com essa realidade, é necessário um preparo psicológico e a certeza de que irá se deparar com 
diversas situações e precisa enfrentá-las sempre com entusiasmo, responsabilidade e compromisso, afinal a educação prisional, por mais que se tente comparar com o ensino regular, jamais terá essa proximidade, haja vista, os discentes virem de realidades totalmente diferenciadas das vivenciadas por alunos do ensino regular. Eles perderam sua liberdade, o direito de ir e vir, precisam reconstruírem suas histórias em um curto espaço tempo e por se tratar da modalidade de Educação de Jovens e Adultos (EJA), exige um esforço bem maior por parte deles e dos professores.

Ao permitir que um presidiário tenha acesso a sala de aula, dar-se a ele a oportunidade de reflexão em torno do contexto social, pois o levará a pensar se há uma possibilidade de retorno ao convívio familiar, este está cansado de viver encarcerado, ele próprio começa acreditar que é capaz de mudar sua história e a partir daí começa a valorizar a educação como um escape para essa transformação. Ainda que não tenhamos políticas públicas específicas para a educação prisional, precisamos acreditar nessa possibilidade de transformação, reconstrução e busca de uma identidade, de não ser mais considerado um simples detento, mas de um indivíduo capaz de reconstruir sua própria história através da educação.

\section{REFERÊNCIAS}

BRASIL. Lei no 7.210, de 11 de julho de 1984. Institui a Lei de Execução Penal. Disponível em: <http://www.planalto.gov.br/ccivil_03/leis/L7210compilado.htm>. Acesso em: 28 nov. 2019.

BRASIL. Lei de diretrizes e Bases da Educação Nacional. LDB.9394/96. São Paulo: Saraiva, 1996.

BRASIL, Lei № 9.394, 20 dez. 1996. Diretrizes e Bases da Educação Nacional.

CLAUDE, Richard Pierre. " Civil-Military/Police Relations" . In: Educating for Human Rights: The Philippines and Beyond, pp. 71-101. Manila/Honolulu: Universidade das Filipinas - Universidade do Havaí, 1996. 
https://www.scielo.br/scielo.php?script=sci_arttext\&pid=S1806-64452005000100003. Acesso em: 10 de jul. 2019.

Constituição da República Federativa do Brasil: (1995). Promulgada em 5 de outubro de 1988. 26 Edição atualizada e ampliada. São Paulo: Saraiva, 2007.

DOTTI, René Ariel, Casos criminais célebres. 3.ed., ver. E ampl. São Paulo: Revista dos Tribunais, 2003, $430 \mathrm{p}$.

DHNET. Diretos Humanos na internet. Comentários ao artigo 13. Disponível em: http://www.dhnet.org.br/direitos/deconu/coment/balestreri.html. Acesso em: 10 de maio. 2019

DHNET. Diretos Humanos na internet. Disponível em: https://www.direitonet.com.br/artigos/exibir/2231/Ressocializacao-atraves-daeducacao. Acesso em 10 de fev. 2019.

FREIRE, P. (1983). Educação e mudança. 7., Rio de Janeiro: Paz e Terra.

FREIRE, P. A importância do ato de ler. (1983). 3., São Paulo: Cortez.

FREIRE, P. A importância do ato de ler, (1994). Em três artigos que se contemplam. 14. São Paulo; Cortez.

FREIRE, P. Pedagogia do oprimido. (1987). 30., Rio de Janeiro: Paz e Terra.

FREIRE, P. Pedagogia da Autonomia. (1997). Saberes necessários a prática educativa. São Paulo: Paz e Terra.

FREIRE, P. e RIVIÈRE, P. (1987). O processo educativo segundo Paulo Freire e Pichon Rivière. São Paulo: Vozes.

GADOTTI, M. (1984). A educação contra a educação: o esquecimento da educação e a educação permanente. 3., Rio de Janeiro: Paz e Terra.

GADOTTI, M. História das idéias pedagógicas. (1998). 6., São Paulo: Ática. 
GADOTTI, M.; FREIRE, P. e GUIMARÃES, S. (1985). Pedagogia: diálogo e conflito. São Paulo: Cortez - Autores Associados.

FOUCAULT, M. 1987. Vigiar e punir: nascimento da prisão. 20ำ ed., Petrópolis, Vozes, $287 \mathrm{p}$.

FOUCAULT, M. (1979). Microfísica do poder. Trad. de Roberto Machado. Rio de Janeiro: Graa.

FOUCAULT, M. Vigiar e punir: (1998). Nascimento da prisão. Trad. de Raquel Ramalhete. 18., Petrópolis: Vozes.

G1. Raio X do sistema prisional em 2017. 06/01/2017. Disponível em: $<$ http://especiais.g1.globo.com/politica/2017/raio-x-do-sistema-prisional/>. Acesso em: 10 de nov.2019.

HISTÓRIA DA LOUCURA. (2001). São Paulo: Editora Perspectiva. Ciências da cognição. Florianópolis: Insular.

NASCIMENTO, Sandra Maria do, Educação de Jovens e Adultos EJA, na Visão de Paulo Freire.2015. http://repositório.roca.utfpr.edu.br:8080/jspui/bitstream/1/4489/1MD EDUMTE 20142 116.pdf. Acesso em: $10 \mathrm{de}$ fev. 2019.

NOVO, Benigno Núñez. A relevância da educação prisional como instrumento de ressocialização. Revista Jus Navigandi, ISSN 1518-4862, Teresina, ano 24, n. 5847, 5 jul. 2019. Disponível em: https://jus.com.br/artigos/74918. Acesso em: 11 de out. 2020.

NOVO, Benigno Núñez. A Educação Prisional Que Recupera. Brasil Escola. Disponível em: https://meuartigo.brasilescola.uol.com.br/educacao/a-educacaoprisional-que-recupera.htm. Acesso em: 20 de ago. 2019. 
OLIVEIRA, Carolina Bessa Ferreira de. A educação escolar nas prisões: uma análise a partir das representações dos presos da penitenciária de Uberlândia (MG). Educ. Pesqui., São Paulo, v.39, n.4, p.955-967, out./dez.,2013.

PLANALTO.

Disponível

em:

http://www.planalto.gov.br/ccivil_03/leis//7210compilado.htm. Acesso em 17 de set. 2019.

PAIVA, Vanilda Pereira. Educação Popular e Educação de Adultos. 5ำ Ed. São Paulo: Loyola, Ibrades, 1987.

PEREIRA, Antonio. A educação de jovens e adultos no sistema prisional brasileiro: o que dizem os planos estaduais de educação em prisões?

PRADO, Luiz Regis. Curso de direito penal brasileiro. vol. 3. 14. ed. São Paulo: RT, 2015.

SALLA, Fernando. As Prisões em São Paulo: 1822-1940. São Paulo: Annablume, 1999.

SANTANA, Maria Silvia Rosa; AMARAL, Fernanda Castanheira. Educação no sistema prisional brasileiro: origem, conceito e legalidade. Revista Jus Navigandi, ISSN 1518-4862, Teresina, ano 25, n. 6291, 21 set. $2020 . \quad$ Disponível em: https://jus.com.br/artigos/62475. Acesso em: 10 fev. de 2020.

SCHICHOR, David. The Corport Contexto of Private Prisions. Crime, Law and Social Change, v. 20, n.2p.113-138, 1993.

TAKADA, Mário Yudi. Evolução histórica da pena no Brasil. ETIC-ENCONTRO DE INICIAÇÃO CIETÍFICA, v.6 n.6, 2010.

VASQUEZ, Eliane Leal. 2008. Sociedade Cativa. Entre cultura escolar e cultura prisional: Uma incursão pela ciência penitenciária. Dissertação de Mestrado. 163 fls. Pontifícia Universidade Católica de São Paulo. São Paulo, 2008. 
VELASCO. Clara. Menos de 1/5 dos presos trabalha no Brasil; 1 em cada 8 estuda. Disponível em: https://g1.globo.com/monitor-da-violencia-/noticia/2019/04/26/menosde-15-do-presos-trabalha-no-brasil-1-em cada-8-estuda.gtml>. Acesso em 15 de set. 2019.

\section{APÊNDICE - REFERÊNCIA DE NOTA DE RODAPÉ}

3. De acordo com estudos realizados não havia uma educação que abrangesse o privado de liberdade, este por sua vez ficava a mercê de todo tipo de violência, não existia nenhuma política pública que beneficiasse o preso, a vida não tinha valor.

Enviado: Agosto, 2020.

Aprovado: Outubro, 2020. 